\title{
TAKHAYUL SEPUTAR KEHAMILAN DAN KELAHIRAN dalam pandangan Orang labuan Bajo, TINJAUAN ANTROPOLOGI SASTRA
}

\author{
Superstitions on Pregnancy and Birth in The View of Labuan Bajo People: A \\ Philological Anthropology Perspective
}

Oleh Uniawati

Kantor Bahasa Provinsi Sulawesi Tenggara

Jalan Haluoleo Kompleks Bumi Praja, Anduonohu, Kendari

Email: uni3q_genit@yahoo.com

\begin{abstract}
Abstrak
Penelitian ini dilandasi oleh pemikiran bahwa takhayul merupakan salah satu bentuk tradisi lisan yang sulit dipisahkan dari kehidupan masyarakat, baik masyarakat tradisional maupun modern. Salah satu kelompok masyarakat yang hingga kini masih kuat terpengaruh dengan pola pemikiran lama adalah kelompok masyarakat Labuan Bajo. Masyarakat Labuan Bajo adalah salah satu kelompok masyarakat tradisional yang di dalamnya subur dengan kepercayaan yang bersifat takhayul. Penelitian ini bertujuan untuk menjawab dua permasalahan, yaitu mengungkapkan bentuk dan isi takhayul yang terdapat di lingkungan masyarakat Labuan Bajo serta mendeskripsikan aspek-aspek budaya masyarakat tersebut berdasarkan takhayul yang terdapat di lingkungan mereka. Untuk menjawab kedua permasalah tersebut, digunakan pendekatan Antropologi Sastra. Data yang dianalisis dalam penelitian ini adalah data yang diperoleh secara lisan di lapangan berupa ungkapan tentang kepercayaan terhadap sesuatu yang bersifat takhayul. Hasil penelitian menunjukkan bahwa orang Labuan Bajo pada dasarnya masih mengakui keberadaan takhayul hingga sekarang, namun tingkat kepercayaannya sudah berkurang dibandingkan dengan kepercayaan yang dimiliki oleh para pendahulunya. Para pendahulu (nenek moyang) orang Labuan Bajo memandang takhayul sebagai suatu bentuk kepercayaan yang akan menimbulkan bahaya atau bencana apabila dilanggar, sedangkan orang Labuan Bajo sekarang sebagian besar memandang takhayul sebagai sarana menyampaikan pendidikan akhlak, etika, dan budi pekerti dalam lingkungannya agar masyarakat hidup lebih beradab dan berbudaya. Untuk itu, beberapa takhayul masih dipelihara dalam komunitas masyarakat tersebut.
\end{abstract}

Kata kunci: tradisi lisan, takhayul, antropologi sastra.

\section{Abstract}

This research was based on the fact that superstitions are a kind of oral tradition that is inherent in the social life of a society, either in modern or traditional ones. The aims of the research are, firstly, to reveal forms and contents of superstitions that live among Labuan Bajo people and secondly, to describe cultural aspects of the people based on their 
superstitions. The author approaches the problems by using literary anthropology. The result shows that superstitions still exist among Labuan Bajo people but in a lower degree. Contrary to their ancestors who thought of superstitions as harmful if they were broken, today the Labuan Bajo people consider superstitions as a means to convey messages of morals and ethics to the young. Therefore, they tend to maintain some superstitions stories in the society.

Keywords: oral traditions, superstitions, literary anthropology.

\section{A. PENDAHULUAN}

Takhayul ${ }^{1}$ adalah ungkapan tradisional dari satu atau lebih syarat, dan satu atau lebih akibat; beberapa dari syarat-syaratnya bersifat tanda, sedangkan yang lainnya bersifat akibat (Dundes, 1961: 25 - 26). Sejalan dengan pendapat itu, Brunvand (1968: 1978) menjelaskan bahwa takhayul mencakup aspek kepercayaan (belief), kelakuan (behaviour), pengalaman-pengalaman (experiences), dan ada kalanya berupa alat, ungkapan, serta sajak. Berangkat dari kedua pernyataan tersebut, takhayul dapat mencerminkan suatu upaya yang dilakukan oleh manusia untuk tetap mempertahankan nilai-nilai dan pranata-pranata yang berlaku dalam suatu kelompok masyarakat. Salah satu upaya yang dilakukan oleh masyarakat adalah dengan menciptakan dan melestarikan suatu takhayul yang tidak boleh dilanggar oleh masyarakat itu sendiri. Pelanggaran yang dilakukan terhadap takhayul tersebut akan melahirkan suatu sanksi yang harus dihadapi oleh setiap masyarakat yang melanggarnya. Takhayul dalam kerangka kebudayaan dapat berisi hal-hal yang bersifat larangan atau "tabu". 2 Misalnya, janganlah menjual silet dan

\footnotetext{
${ }^{1}$ Takhyul sering juga disebut kepercayaan rakyat (folk belief) (Danandjaja, 1986: 153).

2 Tabu itu bersifat larangan atau semacam peringatan yang harus dipatuhi oleh masyarakat sebab jika tidak dipatuhi akan melahirkan suatu konsekuensi hukum yang dapat merugikan diri orang itu sendiri atau kelompok masyarakat. Sebagai sebuah larangan, tabu dapat berupa perbuatan, perkataan karena dapat mengakibatkan adanya suatu kekuatan yang membahayakan apabila tindakan itu dilakukan. Dalam budaya Bugis, "tabu" dikenal dengan istilah pammali "pamali".
}

jarum pada malam hari, karena akan berakibat kebangkrutan pada toko dan usaha yang dijalankan.

Masyarakat yang hidup di era sekarang ini, meskipun menganggap dirinya berada dalam kelompok masyarakat modern, namun tetap tidak dapat menghilangkan pengaruh-pengaruh orang tua dahulu. Pengaruh-pengaruh tersebut dapat berupa pandangan hidup dan pola pikir yang sudah tertanam sejak kecil sehingga sulit untuk melepaskannya begitu saja. Dalam setiap tindakan yang dilakukan, akan tetap tergambar nuansa konservatif ${ }^{3}$ yang diperolehnya dari orang-orang tua ter-dahulu. Artinya, di mana dan kapan pun, setiap orang atau kelompok masyarakat akan selalu berada dalam lingkaran pengaruh konservatisme. Menyinggung soal paham konservatif, akan mengantarkan kita pada pandangan tentang orang-orang atau kelompok masyarakat yang masih terpengaruh dengan pemikiran lama (tidak modern). Biasanya, dalam kelompok masyarakat seperti itulah berkembang halhal yang banyak bersifat takhayul.

Salah satu kelompok masyarakat yang hingga kini masih dapat dikatagorikan sebagai kelompok masyarakat yang masih kuat terpengaruh dengan pola pemikiran lama adalah kelompok masyarakat Labuan Bajo $^{4}$. Masyarakat ini tinggal secara permanen di wilayah atau daerah yang

\footnotetext{
3 Konservatif adalah kolot; bersikap mempertahankan keadaan, kebiasaan, dan tradisi yang berlaku (Sugono, dkk., 2008: 726).

${ }^{4}$ Labuan Bajo adalah nama sebuah desa yang dijadikan sebagai wilayah penelitian. Letak desa ini berada di Kecamatan Wakorumba Utara, Kabupaten Buton Utara, Sulawesi Tenggara.
} 
dekat dengan laut. Bahkan dapat dikatakan bahwa wilayah kediaman orang Labuan Bajo memanjang mengikuti pesisir laut. Alam dan lingkungan yang melingkupi takhayul dalam lingkaran masyarakat tersebut. Sebagaimana yang dikatakan oleh Kridalaksana (1993: 128) bahwa lingkungan (environment) merupakan situasi sosial atau budaya tempat berlangsungnya penggunaan suatu bahasa tertentu.

Takhayul dalam kelompok masyarakat Labuan Bajo dijadikan sebagai pedoman yang harus dipatuhi dalam beraktivitas sehari-hari (bandingkan Balawa, 2010:204-205). Ada semacam ketakutan dalam diri mereka apabila tidak mematuhi larangan-larangan atau peringatan-peringatan yang terkait dengan takhayul yang terdapat dalam kelompok masyarakatnya. Sedikit-banyaknya, hal itu sangat memengaruhi pola pikir dan tindakan masyarakat tersebut. Takhayul dalam hal ini menjadi sangat penting untuk dipatuhi oleh anggota masyarakat tersebut sebab akan melahirkan suatu konsekuensi apabila hal itu tidak diindahkan. Takhayul yang terdapat dalam kelompok sosial orang Labuan Bajo merupakan bentuk dari fakta sosial masyarakat tersebut. Fakta sosial sering tidak pernah jelas dengan sendirinya. Orang tidak dapat melihat kenyataan tanpa juga memprosesnya atas dasar beberapa kriteria kepentingan atau kerangka makna yang telah didapatnya lebih dulu (lihat Hand, 1952: 208).

Melalui penelitian ini, diangkat dua buah permasalahan, yaitu bagaimana bentuk dan isi takhayul yang terdapat di lingkungan masyarakat Labuan Bajo serta bagaimana pula aspek-aspek budaya yang terdapat di dalamnya berdasarkan takhayul yang terdapat di lingkungan mereka. Dengan memahami penjelasan dan penafsiran makna dibalik bentuk dan isi takhayul dalam kelompok orang Labuan Bajo, akan dapat ditemukan aspek-aspek budaya yang tertuang dalam bentuk tata pikir (cognition) dan tata laku (behavior) bagaimana masyarakat tersebut mengekspresikan kebudayaannya dengan kreatif. Untuk itu, mengkaji takhayul dalam pandangan orang Labuan masyarakat ini menjadi salah satu faktor utama yang menyebabkan suburnya katakata

Bajo secara dalam akan mengantarkan pada pemahaman mengenai konteks sosial kemasyarakatan yang berlaku dalam komunitas tersebut.

Data yang dimanfaatkan dalam penelitian ini adalah data lisan yang diperoleh dari lapangan berupa ungkapan yang berisi kepercayaan terhadap sesuatu yang bersifat takhayul ${ }^{5}$. Takhayul yang dianalisis dalam penelitian ini dibatasi pada takhayul yang berhubungan dengan lingkaran hidup manusia yang meliputi masa kelahiran, bayi, dan anak-anak. Pembatasan ini dilakukan mengingat bahwa bagian ini menyangkut proses dan fase hidup manusia. Selain itu, takhayul yang paling banyak ditemukan pada komunitas Labuan Bajo adalah takhayul yang berhubungan dengan masa kelahiran, bayi, dan anak-anak.

Data tersebut dianalisis dengan menggunakan metode kualitatif dengan memanfaatkan tinjauan antropologi sastra untuk mendeskripsikan aspek-aspek budaya orang Labuan Bajo berdasarkan takhayul yang terdapat di lingkungan masyarakat tersebut. Pemilihan metode tersebut dengan pertimbangan bahwa metode kualitatif memberikan perhatian terhadap data alamiah yang melibatkan sejumlah besar gejala sosial yang relevan. Seperti yang dikatakan oleh Ratna (2006: 47) bahwa objek metode kualitatif bukan gejala sosial sebagai bentuk substantif, melainkan makna-makna yang terkandung dibalik tindakan yang justru mendorong timbulnya gejala sosial tersebut.

Pendekatan Antropologi Sastra yang digunakan dalam penelitian ini didasarkan oleh pertimbangan bahwa pendekatan ini menekankan pada kajian karya sastra yang

\footnotetext{
5 Takhayul yang dimaksudkan dalam penelitian ini mengacu pada konsep takhayul berdasarkan pandangan Alan Dundes, yaitu ungkapan yang mengandung sedikitnya dua hal, syarat dan akibat. Dalam hal ini takhayul yang akan dijadikan fokus kajian adalah takhayul dalam lingkungan orang Labuan Bajo.
} 
memuat warisan budaya masa lampau (lihat, Endraswara, 2008:109). Dengan demikian, pendekatan Antropologi Sastra lebih memberikan ruang terhadap sasaran analisis yang akan dilakukan, yakni untuk mendeskripsikan bentuk dan isi takhayul serta aspek-aspek budaya orang Labuan Bajo berdasarkan takhayul yang terdapat di lingkungan mereka.

Teori yang dijadikan sebagai landasan dalam penelitian ini mengacu pada teori-teori yang menyangkut pengertian tentang takhayul dan hal-hal lain yang berkaitan dengan takhayul. Takhayul dalam KBBI (2008:1380) diartikan dengan kepercayaan kepada sesuatu yang dianggap ada atau sakti, tetapi sebenarnya tidak ada atau tidak sakti. Takhayul adalah hal-hal yang sering kita dengar dari orang tua kita atau kakek/nenek kita. Takhayul tersebut tentunya berawal dari banyaknya kasus yang terjadi karena melanggar pantangan dalam sebuah takhayul tersebut meski segala sesuatunya adalah bersandarkan atas kehendak Tuhan. Takhayul tersebut kemudian berkembang menjadi sebuah kepercayaan yang tidak berdasarkan pada logika sehingga dianggap tidak dapat dipertanggungjawabkan secara ilmiah (Danandjaja, 1986: 153). Berhubung kata "takhayul" mengandung arti merendahkan atau menghina, maka ahli folklor modern lebih senang menggunakan istilah kepercayaan rakyat (folk belief) atau keyakinan rakyat daripada takhayul karena takhayul berarti sesuatu yang sebenarnya tidak ada atau tidak masuk akal.

Sikap beberapa ahli yang memandang konsep takhayul sebagai sesuatu yang tidak masuk akal menurut beberapa ahli folklor tidak dapat dibenarkan karena pada kenyataannya dapat dikatakan bahwa tidak ada orang yang bagaimanapun modernnya, dapat bebas dari takhyul, baik dalam hal kepercayaannya maupun dalam hal kelakuannya (Brunvand, 1968: 178).

Takhayul memiliki hubungan yang erat dengan lingkaran hidup manusia, alam gaib, dan alam semesta dan dunia. Menurut Danandjaja (1986: 155), alasan mengapa takhyul tetap bertahan hidup di tengah masyarakat yang sudah modern hingga saat ini disebabkan oleh cara berpikir yang salah, koinsidensi, predileksi (kegemaran), perasaan ketidaktentuan akan tujuan-tujuan yang sangat didambakan, ketakutan akan hal-hal yang tidak normal atau penuh resiko dan takut akan kematian, serta pengaruh kepercayaan bahwa tenaga gaib dapat tetap hidup berdampingan dengan ilmu pengetahuan dan agama. Sebab lain tentang eksistensi takhyul hingga saat ini adalah adanya asumsi bahwa terdapat hubungan erat antara benda-benda yang sebenarnya tidak ada hubungan.

Dalam masyarakat Labuan Bajo, takhayul hidup berdampingan dengan jenis folklor lain, misalnya nyanyian rakyat atau mitos. Keberadaannya menjadi pendamping pranata yang terdapat dalam lingkaran hidup masyarakat tersebut. Posisi takhayul dalam pandangan masyarakat tersebut menempati ruang yang tidak dapat terjamah oleh anggota masyarakatnya. Takhayul dalam hal ini dipandang penting dan perlu untuk selalu dipatuhi. Sadar atau tidak sadar, pengaruh takhayul sangat kuat menopang kepercayaan masyarakatnya (bandingkan Ahimsa-Putra, 2006). Unsur takhayul sangat sulit untuk dapat lepas dalam pola pikir dan pandangan masyarakat tersebut, oleh karena itu sangat menarik untuk diamati.

\section{B. HASIL DAN BAHASAN}

\section{Takhayul Seputar Kehamilan dan Kelahiran pada Masyarakat Labuan Bajo}

Takhayul yang terdapat dalam masyarakat di Labuan Bajo yang ditemukan sangat beragam. Keberagaman itu menunjukkan bahwa takhayul dalam masyarakat tersebut memiliki hubungan yang erat dengan segala aktivitas keseharian masyarakat. Takhayul tidak saja diketahui oleh orang tua saja, tetapi juga diketahui oleh anak-anak muda. Perbedaannya terletak pada keyakinan masing-masing. Ada kecenderungan bahwa anak-anak muda tidak lagi begitu memercayai isi sebuah takhayul seperti halnya orang tua mereka sehingga terkadang mengabaikan suatu takhayul tertentu. Namun, bukan berarti bahwa mereka lepas dari takhayul sebab disadari 
atau tidak takhayul tidak akan bisa lepas dari kehidupan seseorang.

Kesanksian beberapa orang terhadap suatu takhayul tidak signifikan dengan sikap mereka. Meskipun sanksi, mereka cenderung tetap berhati-hati apabila mengetahui telah melakukan pelanggaran terhadap suatu takhayul tertentu. Jadi, dalam hal ini mereka sesungguhnya tidak bisa melepaskan diri secara total dari takhayul. Kalaupun ada yang bisa lepas dari takhayul tertentu, bukan berarti bahwa dirinya terbebas dari takhayul. Ada kalanya perkataan atau pun sikap yang ditampakkan mengarah kepada hal-hal yang bersifat takhayul, tetapi kurang disadari. Demikian pula dengan sebagian orang Labuan Bajo, baik orang-orang tua yang mengaku tidak memercayai takhayul maupun anak-anak muda yang menganggap takhayul kuno, tanpa mereka sadari bahwa hakikat suatu takhayul akan selalu berdampingan dengan hidup yang dijalani oleh manusia dalam berinteraksi dengan sesamanya.

Berikut adalah takhayul orang Labuan Bajo yang terdapat di sekitar lingkaran hidup manusia yang berhubungan dengan kelahiran, masa bayi, dan masa kanak-kanak. Untuk memudahkan analisis, takhayul diberi kode (T) dan isi takhayul diberi kode huruf kecil berdasarkan urutannya.

a. Bayi yang baru dilahirkan ditidurkan atau dibaringkan di atas kelopak mayang pinang agar tidak diganggu oleh mahluk halus. (Ta)

b. Bayi yang hendak ditinggalkan, di dekatnya disimpan benda-benda tajam seperti pisau dan cermin agar tidak diganggu oleh mahluk halus. (Tb)

c. Orang hamil terutama yang hendak keluar rumah harus selalu membawa barang-barang pedas seperti bawang merah, bawang putih, pisau, kariango, dan sebagainya. (Tc)

d. Orang hamil dan orang yang telah melahirkan tidak diperbolehkan keluar rumah pada waktu subuh dengan magrib sebab ditakutkan akan mendapat gangguan mahluk halus. (Td) e. Orang yang sedang hamil dilarang melangkahi tali jangkar kecuali langsung menginjak tali tersebut atau mengangkatnya lalu lewat di bawahnya sebab dikhawatirkan plasenta anaknya akan tertinggal atau terkait di dalam perut seperti jangkar yang terkait dan susah dilepas. (Te)

f. Apabila menghendaki bayi yang dilahirkan terlahir dengan keadaan bersih, pada saat hamil selalu melakukan mandi bulan, baik suami maupun istri. (Tf)

g. Apabila ingin mendapatkan kemudahan dalam melahirkan, istri ataupun suami harus selalu bersikap ikhlas selama hamil dan tidak boleh sedikit pun ada susah. Jika ada yang datang ke rumah meminta sesuatu hendaknya selalu diberi dan jika memang tidak mampu harus disiramkan air pada jejak kaki orang yang meminta pada saat dia beranjak pergi. $(\mathrm{Tg})$

h. Ari-ari bayi dimasukkan ke dalam tempurung kelapa sebab tempurung kelapa itu diibaratkan sebagai kepala manusia yang memiliki dua mata, satu hidung, dan satu mulut seperti yang terdapat dalam tempurung kelapa. (Th)

i. Jangan makan di atas kasur atau tangga nanti mamamu pendek umur atau cepat mati. (Ti)

\section{Analisis Takhayul Seputar Kehamilan dan Kelahiran pada Masyarakat Labuan Bajo \\ Menurut Danandjaja (1986:154)}

takhayul menyangkut kepercayaan dan praktek (kebiasaan). Pada umumnya, takhayul diwariskan melalui media tutur kata. Tutur kata ini dijelaskan dengan syaratsyarat, yang terdiri dari tanda-tanda (signs) atau sebab-sebab (causes), dan yang diperkirakan akan ada akibatnya (result). Contoh, "Jika terdengar suara katak (tanda), maka akan turun hujan (akibat) atau "jika kita memandikan kucing (sebab), maka akan segera turun hujan (akibat). Contoh yang pertama berdasarkan hubungan sebab akibat menurut hubungan asosiasi ${ }^{6}$,

${ }^{6}$ Asosiasi adalah bayangan-bayangan dalam pikiran yang menimbulkan bayangan-bayangan 
sedangkan contoh yang kedua, yaitu perbuatan manusia yang dilakukan dengan sengaja yang menyebabkan suatu "akibat". Hal itu biasanya dihubungkan dengan ilmu gaib (magic) ${ }^{7}$.

Berhubung kata "takhayul" adalah semacam ungkapan tradisional, maka ia termasuk jenis folklor, tetapi berbeda dengan ungkapan tradisional lainnya seperti bahasa rakyat, peribahasa, teka-teki, sajak, nyanyian rakyat, cerita rakyat, dan sebagainya (Danandjaja, 1986:154). Takhayul berdasarkan asumsi atas kesadaran atau bukan kesadaran mengenai syaratsyarat (conditions) dan akibat-akibat (results), sebab dan akibat dalam dunia kehidupan sehari-hari. Walaupun asumsi itu tidak ilmiah, aspek kepercayaan terhadap hal-hal yang ditabukan sangat luas persebarannya di semua lapisan masyarakat (Brunvand, 1968: 179).

Berdasarkan gambaran tersebut di atas, maka terlihat bahwa takhayul melingkupi segala aspek kehidupan manusia. Khusus takhayul yang terdapat di sekitar lingkaran hidup orang Labuan Bajo, aspek kehidupan yang paling dekat dengan persoalan takhayul adalah aspek kelahiran, masa bayi, dan kanak-kanak. Hal itu kemungkinan besar disebabkan oleh sebuah anggapan bahwa pada fase hidup tersebut merupakan fase-fase awal kehidupan manusia sehingga sangat rentan oleh hal-hal yang rawan. Untuk itu, lahirlah kemudian takhayul-takhayul sebagai pengukuh atas keadaan tersebut agar manusia bisa mematuhinya.

Salah satu contoh takhayul mengenai kelahiran dan masa bayi, orang di Labuan Bajo menganggap bahwa bayi diibaratkan sebagai mahluk yang masih

baru, sehingga terjadi suatu rangkaian bayanganbayangan (Koentjaraningrat dalam Danandjaja, 1986: 165).

${ }^{7}$ Ilmu gaib (magic) dapat dibagi ke dalam ilmu gaib putih (white magic) yakni ilmu gaib yang dipraktekkan untuk maksud-maksud baik atau untuk menolong orang dan ilmu gaib hitam (black magic) yakni ilmu gaib yang dipraktekkan untuk mencelakai orang lain (Koentjaraningrat dalam Danandjaja, 1986: 165). suci dan harum, oleh sebab itu mahluk halus sangat gemar terhadap bayi. Untuk itu, bayi yang baru dilahirkan hendaknya ditidurkan atau dibaringkan di atas kelopak mayang pinang agar tidak diganggu oleh mahluk halus (Ta). Contoh lain yang masih berhubungan dengan bayi yang baru dilahirkan adalah ketika hendak meninggalkan bayi, di dekatnya disimpan bendabenda tajam seperti pisau dan cermin agar tidak diganggu oleh mahluk halus (Tb). Takhayul tersebut jika dilihat dari segi strukturnya terjadi berdasarkan hubungan dua hal, yaitu tanda dan akibat. Bayi yang baru dilahirkan dan kelopak mayang adalah sebuah tanda yang menyimbolkan sesuatu yang suci, sedangkan benda-benda tajam seperti pisau dan cermin sebagai tanda perlindungan diri atau tameng. Mendapat gangguan dari mahluk halus merupakan akibat yang ditimbulkan apabila sesuatu yang suci itu tidak dijaga atau diperlakukan dengan baik.

Takhayul yang berhubungan dengan orang hamil pada lingkungan masyarakat di Labuan Bajo menyangkut hal-hal pada apa yang boleh dan tidak boleh dilakukan oleh orang yang sedang hamil. Misalnya, orang hamil terutama yang hendak keluar rumah harus selalu membawa barang-barang pedas seperti bawang merah, bawang putih, pisau, dariango ${ }^{8}$, dan sebagainya (Tc). Ada pula takhayul tentang orang hamil dan orang yang telah melahirkan yang dilarang keluar rumah pada waktu subuh dengan magrib sebab ditakutkan akan mendapat gangguan dari mahluk halus (Td). Kedua takhayul tersebut terjadi berdasarkan pada hubungan sebab dan akibat. "Sebab"nya adalah orang hamil keluar rumah dan akibatnya adalah mendapat gangguan makhluk halus. Oleh karena itu, sebagai konversinya adalah

\footnotetext{
8 Dariango adalah sejenis tanaman merambat, pedas, yang diyakini masyarakat setempat mampu menangkal gangguan mahluk halus. Tanaman ini lumrah digunakan oleh orang yang sedang hamil atau seorang bayi dengan cara mengikatkan barang tersebut pada badan (biasanya pada pinggang) dengan tujuan untuk menjaga diri agar tidak diganggu mahluk halus.
} 
harus membawa barang-barang pedas agar tidak mendapatkan gangguan dari mahluk halus. Konversi dalam hal ini berfungsi untuk mencegah agar tidak terjadi "akibat" yang ditimbulkan oleh suatu "sebab"

Ada sebuah fakta yang pernah terjadi pada masyarakat Labuan Bajo yaitu seorang ibu yang baru melahirkan keluar rumah pada waktu Magrib dan tidak kembali lagi ke rumah. Ibu tersebut diketahui kemudian telah menghilang dan hingga saat ini tidak dapat ditemukan kembali. Kejadian tersebut menurut informan, adalah fakta sebab dianggap benarbenar pernah terjadi oleh masyarakat. Hingga kini, kejadian tersebut terusmenerus diwariskan kepada setiap generasi yang tinggal di Labuan Bajo melalui cerita dan dianggap sebagai sebuah kebenaran yang tidak boleh terulang kembali. Itulah sebabnya masyarakat di Labuan Bajo sangat percaya terhadap takhayul tersebut sehingga tidak ada orang hamil yang berani melanggarnya.

Jika ditelisik lebih jauh, munculnya takhayul tersebut yang berkaitan dengan persoalan waktu, yaitu waktu Subuh dan Magrib, ada pesan khusus yang terkandung dibalik larangan itu. Waktu Subuh dan Magrib bagi pemeluk agama Islam jelas adalah waktu untuk melaksanakan kewajibannya yaitu mendirikan salat wajib Subuh dan Magrib sehingga jika masih berseliweran di luar rumah menyebabkan seseorang akan lalai dan tidak menjalankan kewajiban. Selain itu, Subuh dan Magrib adalah sebuah waktu transisi atau peralihan dari siang menuju malam dan malam menuju siang sehingga pada waktu-waktu seperti itu banyak mahluk halus yang berkeliaran. Keadaan seperti inilah yang bisa menjadi salah satu pemicu seseorang apalagi wanita yang sedang mengandung sangat rawan untuk berada di luar rumah. Seperti yang telah disinggung pada bagian sebelumnya, wanita hamil diibaratkan memiliki aroma tubuh yang harum dan sangat disukai oleh mahluk halus. Untuk itu, wanita yang sedang hamil harus benarbenar menjaga keselamatan diri dan bayi yang sedang dikandungnya. Dalam rangka menerapkan peringatan itu, maka lahirlah kemudian sebuah takhayul tentang larangan bagi orang hamil keluar rumah yang disertai dengan sebuah cerita pendamping agar masyarakat benar-benar mematuhinya sehingga tidak terjadi suatu pelanggaran yang akan merugikan diri sendiri.

Selanjutnya, ada pula takhayul tentang wanita hamil yang hendak melahirkan dengan mudah atau pun melahirkan bayi dalam kondisi bayi yang bersih. Misalnya, (1) apabila menghendaki bayi yang dilahirkan terlahir dengan keadaan bersih, pada saat hamil selalu melakukan mandi bulan, baik suami maupun istri (Tf). Takhayul lain, (2) apabila ingin mendapatkan kemudahan dalam melahirkan, istri ataupun suami harus selalu bersikap ikhlas selama hamil dan tidak boleh sedikit pun ada susah. Jika ada yang datang ke rumah meminta sesuatu hendaknya selalu diberi dan jika memang tidak mampu harus disiramkan air pada jejak kaki orang yang meminta pada saat dia beranjak pergi $(\mathrm{Tg})$.

Kedua takhayul tersebut memiliki struktur yang sama, tetapi mengandung aspek yang berbeda. Takhayul pertama hanya memenuhi dua unsur, yaitu sebab dan akibat, sedangkan takhayul kedua lebih lengkap karena memiliki tiga unsur, yaitu sebab, akibat, dan konversi. Takhayul pertama mengandung sebuah tanda yaitu bayi yang terlahir bersih (akibat) dan mandi bulan bagi pasangan suami istri (sebab). Takhayul kedua, mendapat kemudahan dalam melahirkan (akibat), suami dan istri harus selalu bersikap ikhlas dan selalu memberi (sebab), dan jika tidak mampu memberi hendaknya menyiramkan air pada jejak orang yang meminta pada saat orang tersebut sudah beranjak pergi (konversi). Struktur takhayul seperti itu bukanlah aturan yang paten, melainkan sebagai syarat untuk sebuah ungkapan bisa dikatakan sebagai takhayul. Banyak pula takhayul lain yang strukturnya tidak seperti itu, ada juga yang letak konversinya di tengah atau letak sebabnya di awal dan akibat pada bagian akhir. Yang terpenting adalah takhayul mengandung paling kurang dua aspek, yaitu sebab dan akibat atau tanda dan akibat. 
Aspek budaya apa yang terkandung dari kedua takhayul tersebut adalah tentang kebiasaan orang Labuan Bajo untuk hidup ikhlas dan ringan tangan, yakni mudah menolong orang yang susah. Mengapa takhayul seperti ini dikenakan pada wanita yang sedang hamil? Jawabannya adalah wanita hamil merupakan sarana yang tepat untuk menanamkan norma pada bayi yang ada di dalam kandungannya. Seperti yang biasa diwacanakan oleh pakar pendidikan anak bahwa idealnya pendidikan yang diberikan kepada anak dimulai ketika bayi masih ada di dalam kandungan ibunya. Dari sini, dapat dilihat relevansi antara aspek takhayul dengan aspek pendidikan yang tepat diterapkan pada anak. Takhayul ini sekaligus menjadi sebuah penanda kearifan leluhur orang Labuan Bajo yang sudah menyadari tentang arti penting sebuah pendidikan. Kesadaran itu kemudian dikemas dalam bentuk takhayul sebagai cermin kesederhanaan jiwa dan budi para penutur takhayul tersebut.

Takhayul lain yang masih berhubungan dengan wanita hamil menurut orang Labuan Bajo, yaitu wanita yang sedang hamil dilarang melangkahi tali jangkar kecuali langsung menginjak tali tersebut atau mengangkatnya lalu lewat di bawahnya sebab dikhawatirkan plasenta anaknya akan tertinggal atau terkait di dalam perut seperti jangkar yang terkait dan susah dilepas (Te). Takhayul tersebut dari segi struktur mengandung aspek sebab yaitu wanita hamil dilarang melangkahi jangkar dan sebagai akibat adalah plasenta bayinya akan tertinggal di dalam perut. Struktur yang dimiliki takhayul ini pada dasarnya tidak berbeda dengan struktur takhayul sebelumnya, yakni mengandung aspek sebab dan akibat.

Takhayul ini mengindikasikan hubungan yang dekat antara kehidupan orang Labuan Bajo dengan laut. Dapat dipahami sebab letak Desa Labuan Bajo secara geografis dekat dengan laut. Takhayul yang menyinggung soal "jangkar" tentu saja tidak akan terlahir dari lingkungan masyarakat pegunungang sebab "jangkar" hanya digunakan dalam kaitannya dengan kegiatan melaut. Larangan bagi wanita hamil untuk melangkahi tali jangkar dari aspek budaya orang Bajo jelas menunjukkan pentingnya menjaga keagungan laut beserta hal-hal yag berkaitan dengannya sehingga manusia tidak boleh berbuat sesuatu yang dianggap kurang menghargai. Takhayul ini diberlakukan pada wanita hamil sebab dengan cara seperti itu, maka orang lebih mudah mematuhinya terutama bayi yang ada di dalam kandungannya secara tidak langsung ikut pula merasakannya.

Selanjutnya, ada pula takhayul lain yang memiliki hubungan dengan cara memperlakukan ari-ari bayi. Takhayul tersebut berupa anggapan bahwa kepala manusia diibaratkan seperti kelapa, oleh karena itu ari-ari bayi dimasukkan ke dalam tempurung kelapa (Th). Kepala dan kelapa dalam perumpamaan tersebut adalah dua hal yang menarik ditinjau dari sudut estetika dan logika bahasa. Secara estitika, kepala dan kelapa hampir memiliki kesamaan bunyi penuh. Yang membedakan hanya dari segi penempatan konsonan /p/ dan /1/. Kedua konsonan ini hanya bertukar tempat saja dengan kedudukan vokal yang sama sehingga bunyi yang dihasilkan hampir sama. Hal itu menimbulkan efek estetika tersendiri dibandingkan apabila kepala diumpamakan dengan hal lain.

Secara logika bahasa, antara kepala dengan kelapa memiliki kesamaan fisik yang hampir menyerupai satu sama lain. Pertama, sama-sama berbentuk bulat. Kedua, pada batok kelapa terdapat tanda yang menyerupai mata, hidung, dan mulut manusia. Kedua kesamaan itu bisa menjadi alasan mengapa keduanya disandingkan dalam wujud perumpamaan. Hal ini mengindikasikan bahwa budaya orang Labuan Bajo masih memandang suatu bentuk kelahiran sebagai harapan baru atau tunas baru dalam menjalani hidup yang lebih baik dan memiliki fungsi positif, yakni berguna bagi masyarakat. Ibaratnya seperti kelapa, penawar haus bagi orang yang dahaga sekaligus mengenyangkan bagi orang yang sedang lapar. Selain itu, pohon kelapa merupakan tanaman yang mudah bertunas sehingga dapat tumbuh di mana saja. Jadi, tindakan orang tua yang memasukkan ari-ari bayinya ke dalam 
tempurung kelapa merupakan suatu upaya dan doa untuk anaknya agar kelak tumbuh menjadi manusia yang berguna bagi sesama.

Takhayul selanjutnya yang ditemukan dalam masyarakat Labuan Bajo dan masih tergolong dalam kelompok ini terkait dengan masa anak-anak. Pada masa ini, anak-anak umumnya masih dalam tahap mencari, mengenal, dan belajar banyak hal tentang segala sesuatu yang terdapat di sekelilingnya. Oleh karena itu, pada usia anak-anaklah waktu yang tepat untuk mengenalkan dan mengajarkan etika kepadanya. Segala tindak-tanduk yang diperlihatkan oleh anak, besar-kecilnya sangat tergantung pada tindak-tanduk yang diperlihatkan oleh orang di sekelilingnya. Kondisi semacam ini oleh orang tua dahulu cukup dipahami sehingga mereka punya konsep atau cara tersendiri dalam mengenalkan dan mengajarkan etika pada seorang anak. Lepas dari konsep atau cara apa pun yang dipilih oleh orang tua, tujuannya hanya satu yaitu mengajarkan anak hidup beretika, disiplin, dan teratur.

Konsep atau cara yang paling konkrit dilihat pada masa ini adalah melalui penanaman pemahaman dan pola pikir terhadap sesuatu yang secara logika kurang berterima. Hal itulah yang kemudian orang kenal dengan istilah takhayul. Misalnya, jangan makan di atas kasur atau tangga nanti mamamu pendek umur atau cepat mati (Ti). Takhayul tersebut dalam orang Labuan Bajo disampaikan kepada anak yang gemar makan sambil tiduran di atas tempat tidur. Dari segi struktur, takhayul tersebut terdiri dari dua aspek yaitu sebab dan akibat. Jangan makan di atas tempat tidur atau tangga (sebab) dan nanti mamamu pendek umur atau cepat mati (akibat). Jika dicermati, takhayul ini tidak memiliki aspek konversi. Artinya, tidak ada cara yang dapat dilakukan untuk menghindari "akibat" yang ditimbulkan oleh "sebab". Oleh karena tidak adanya kompromi bagi seseorang yang melanggar takhayul ini, maka seseorang tidak akan berani dan memandang sepele takhayul ini. Selain itu, akibat yang dimbulkan oleh sebuah pelanggaran sangat berat sebab terkait dengan orang tua (ibu) yang bisa menjadi penyebab kematiannya.

Anak-anak yang disodorkan takhayul seperti itu tentu akan menerima dalam kepolosannya sebagai anak-anak sehingga tidak akan berani untuk melakukan pelanggaran. Mereka masih sangat sulit untuk mencerna lebih dalam takhayul dan belum dapat membedakan sisi mana yang benar dan keliru. Mereka hanya memahami bahwa apabila makan di atas tempat tidur atau tangga akan mengakibatkan mamanya cepat mati. Usia anak-anak yang disodorkan dengan wacana seperti itu akan menjadi sangat ketakutan sehingga cenderung tidak berani melanggar. Dengan demikian, tujuan orang tua untuk mendidik anak akan tercapai.

Takhayul tersebut mengindikasikan suatu budaya dalam masyarakat di Labuan Bajo tentang sikap seorang anak terhadap orang tua. Pada dasarnya, anak-anak masih sangat tergantung pada orang tua sehingga tidak berani lepas darinya. Budaya seperti ini umumnya kental hidup pada lingkungan orang timur. Berbeda dengan anak-anak yang tumbuh dalam lingkungan budaya barat yang sedari kecil sudah dididik secara mandiri sehingga tidak terlalu bergantung pada orang tua. Kondisi seperti inilah yang menjadi salah satu inspirasi bagi orang tua dulu untuk menciptakan takhayul tersebut.

Dewasa ini, pola pikir anak-anak yang sudah berkembang jauh dibandingkan dengan pola pikir anak-anak pada dasawarsa sebelumnya membuat mereka semakin kritis dan tingkat keingintahuan yang kian meningkat. Ketika disodorkan sebuah takhayul, mereka cenderung menanyakan kembali pemahamannya secara logis. Demikian pula dengan kondisi yang terdapat di lingkungan orang Labuan Bajo. Anak-anak di sana tidak lagi sepenuhnya memercayai takhayul ini sebab secara logika mereka tidak menemukan hubungan yang signifikan antara makan di tempat tidur atau tangga dengan kematian ibu. Walaupun demikian, ada kesan bahwa mereka juga tidak lantas mengabaikan takhayul tersebut sebab tetap tidak mau 
melakukan tindakan yang dilarangkan pada takhayul tersebut.

Lepas dari percaya atau tidak percaya dan patuh atau tidak patuh terhadap takhayul tersebut, yang paling penting adalah pencapaian tujuan dari tahayul itu. Jika anak-anak dapat berperilaku baik dan beretika tanpa dipengaruhi oleh sebuah takhayul, mengapa tidak? Hanya saja, wacana tentang hilangnya takhayul dalam kehidupan masyarakat sangat sulit untuk dibuktikan sebab takhayul tidak akan pernah lepas dari diri seseorang. Hilangnya suatu takhayul akan tergantikan pula oleh takhayul lain yang berbeda dan akan terus seperti itu.

\section{Bentuk Takhayul Orang Labuan Bajo}

Takhayul berdasarkan pandangan Dundes (1961: 25-26) adalah ungkapan tradisional dari satu atau lebih syarat, dan satu atau lebih akibat; beberapa dari syaratsyaratnya bersifat tanda, sedangkan yang lainnya bersifat akibat. Pandangan tersebut menurut Jan Harold Brunvand jauh lebih baik daripada pandangan-pandangan merendahkan sebelumnya tentang takhayul. Takhayul pada kenyataannya tidak terdapat pada satu tempat saja. Takhayul berada pada semua lapisan masyarakat sehingga memungkinkan mengkaji takhayul di beberapa daerah dengan pendekatan yang sama.

Takhayul dalam masyarakat Labuan Bajo menyangkut kepercayaan dan praktek (kebiasaan). Pada umumnya, ia diwariskan secara lisan melalui media tutur kata. Tutur kata ini dijelaskan dengan syarat-syarat, yang terdiri dari tanda-tanda (signs) atau sebab-akibat (causes), dan yang diperkirakan akan ada akibatnya (result). Misalnya, bayi dianggap sebagai mahluk yang masih suci dan harum, (tanda) oleh sebab itu mahluk halus sangat gemar terhadap bayi (akibat); untuk itu, bayi yang baru dilahirkan ditidurkan atau dibaringkan di atas kelopak mayang pinang agar tidak diganggu oleh mahluk halus (conversi). Contoh lain, jika ingin bayi terlahir bersih (akibat), pasangan suami istri harus mandi bulan (sebab).
Kedua contoh takhayul tersebut didasarkan oleh hubungan sebab dan akibat. Takhayul pertama cenderung dipe-ngaruhi oleh hubungan sebab, akibat, dan konversi yang bersifat asosiasi, sedangkan takhayul kedua lebih bersifat magis yang disebabkan oleh suatu kepercayaan terha-dap adanya kekuatan gaib atau sakti.

Secara umum, bentuk takhayul orang Labuan Bajo selalu terdiri dari dua aspek, yaitu sebab dan akibat, tanda dan akibat, tanda dan konversi. Sangat sedikit takhayul yang ditemukan mengandung tiga aspek, misalnya takhayul yang mengandung aspek tanda, sebab, dan akibat atau aspek lainnya. Namun demikian, bentuk takhayul secara keseluruhan memiliki pola yang relatif sama.

Dari segi struktur kalimat, rancang bangun teks takhayul adalah sebuah kalimat majemuk yang diawali dengan kata "jika/ apabila" atau "jangan" atau kadang-kadang kata lain yang maknanya sama dengan kata pengandaian atau pun larangan. Kata "jika/ apabila" atau "jangan", disusul dengan hal (perbuatan) yang dilarangkan kemudian ditambahkan dengan kata penghubung "karena", dan terakhir diakhiri dengan pernyataan tentang keburukan atau akibat yang akan ditimbulkan oleh perbuatan yang dilarangkan itu.

Bentuk/pola takhayul orang Labuan Bajo dapat digambarkan melalui skema 2 berikut.

Skema 2 Bentuk/PolaTakhayul Orang Labuan Bajo

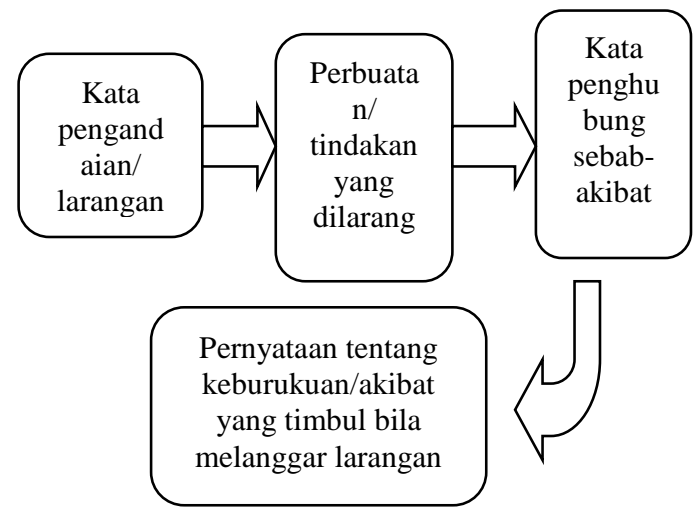

Bentuk/pola lain takhayul orang Labuan Bajo dapat digambarkan melalui skema 3 berikut. 
Skema 3 Bentuk/Pola Lain Takhayul Orang Labuan Bajo

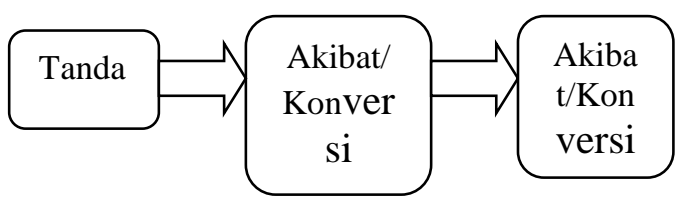

\section{Pandangan Orang Labuan Bajo terhadap Takhayul}

Pengetahuan masyarakat di Labuan Bajo tentang takhayul merupakan warisan dari para leluhur yang diwariskan secara lisan. Sebagai sebuah tradisi lisan, takhayul lambat-laun mengalami pergeseran yang drastis sehingga pemahaman masyarakat terhadap takhayul kian mengikis pula. Takhayul kini dipahami sebatas pada halhal yang tidak masuk akal sehingga "tidak wajib" untuk dipercaya. Kepercayaan yang dimiliki oleh masyarakat Labuan Bajo pada umumnya adalah kepercayaan pada Allah swt. Hal itu tidak mengherankan sebab masyarakatnya adalah masyarakat yang mayoritas beragama Islam.

Masuknya agama Islam memang menjadi salah satu sebab pergeseran pola pandang masyarakat di Labuan Bajo terhadap takhayul. Selain itu, perkembangan teknologi pun turut mendukung semakin terpinggirkannya takhayul dalam pandangan masyarakat tersebut. Masyarakat kian cerdas dan mulai menyadari bahwa hal-hal yang sulit dicerna secara logika merupakan produk masa lampau yang menandakan keterbelakangan hidup. Namun, di balik semua itu, masyarakat kurang menyadari tentang esensi sebuah takhayul sebagai pedoman dan ajaran hidup yang mengarahkan pada hidup yang lebih berbudaya.

Pandangan masyarakat Labuan Bajo terhadap takhayul yang sedikit mulai bergeser secara tersirat menginformasikan bahwa kondisi tersebut tidak berarti bahwa takhayul yang diketahui oleh masyarakat tersebut lantas hilang. Nyatanya, penulis berhasil menjaring beberapa data tentang takhayul yang masih diketahui oleh masya- rakat tersebut. Beberapa di antara takhayul tersebut ada yang kedudukannya masih kental diyakini sebagai sebuah kebenaran dan ada pula yang kurang diyakini atau bahkan sebatas diketahui saja oleh masyarakat penuturnya.

Ada perbedaan pola pandang yang mendasar antara masyarakat Labuan Bajo yang hidup pada zaman dulu dengan masyarakat Labuan Bajo yang hidup pada zaman modern atau masa sekarang. Perbedaan tersebut memengaruhi tingkat kepercayaan dan keyakinan masyarakat terhadap akibat yang ditimbulkan oleh pelanggaran terhadap suatu takhayul tertentu. Artinya, masyarakat sekarang cenderung lebih memahami suatu takhayul sebagai sarana untuk menanamkan nilai-nilai etika atau sopan santun agar masyarakat hidup lebih beradab. Berbeda dengan masyarakat zaman dulu yang cenderung memandang takhayul sebagai suatu bentuk kepercayaan dan larangan yang bisa menimbulkan bahaya atau bencana apabila dilanggar dan tidak mematuhinya.

Perbedaan pola pandang tersebut tidak berarti "mematikan" keberadaan takhayul dalam masyarakat Labuan Bajo sebab masyarakat tersebut dari zaman dulu hingga sekarang tetap mengakui bahwa takhayul merupakan sesuatu yang baik dan berguna untuk dijadikan pedoman dalam bersikap. Namun, perlu diakui bahwa kuatnya pengaruh kehidupan modern di era global saat ini telah mengakibatkan pula semakin berkurangnya perhatian dan keseriusan masyarakat Labuan Bajo untuk memelihara takhayul tersebut sebagai bagian tradisi lisan yang penting untuk dijaga eksistensinya. Kondisi ini makin parah dengan tidak adanya dukungan sikap dari pewaris dan pemerhati tradisi lisan, khususnya di Labuan Bajo. Jumlah pewaris dan pemerhati tradisi lisan, khususnya takhayul, pada masyarakat Labuan Bajo semakin berkurang sehingga akan mempengaruhi upaya pemertahanan tradisi lisan tersebut.

Perlu dipahami bahwa takhayul sebagai bagian dari tradisi lisan masyarakat Labuan Bajo merupakan alat yang dapat 
dipakai untuk menguraikan fenomena dan aspek-aspek budaya masyarakat setempat. Melalui pengamatan serius terhadap takhayul yang terdapat pada masyarakat Labuan Bajo, kita akan dihadapkan pada suguhan sebuah landscap kebudayaan yang menarik untuk dinikmati karena memberikan banyak informasi budaya. Informasi tersebut dapat mengantarkan pada pemahaman tentang budaya orang Labuan Bajo sehingga dapat memperkaya khasanah pengetahu-an kebudayaan kita.

Hasil penelaahan terhadap takhayul orang Labuan Bajo menunjukkan aspekaspek budaya masyarakat tersebut yang meliputi kepercayaan masa lampau terhadap adanya suatu kekuatan gaib yang mengelilingi kehidupan manusia. Persoalan nilai, etika, dan pendidikan budi pekerti juga tidak lepas dari kandungan isi suatu takhayul tertentu. Ada suatu indikasi yang menegaskan bahwa keberadaan takhayul tersebut tidak lepas dari harapan dan keinginan masyarakat dulu untuk mengajarkan dan mendidik masyarakat agar hidup lebih beradab dan berbudaya. Misalnya, takhayul yang berbunyi, wanita hamil dilarang keluar rumah pada waktu Magrib dan Subuh nanti diganggu mahluk gaib. Takhayul tersebut memperlihatkan kondisi budaya yang terdapat di lingkungan masyarakat Labuan Bajo pada zaman dulu tentang anggapan masyarakat terhadap wanita yang keluar rumah pada waktu malam atau Subuh. Seyogyanya, wanita pada malam dan Subuh hari tetap berada di rumah untuk menghindari omongan negatif atau fitnah masyarakat tentang dirinya karena pada waktu-waktu itu sangat rawan mendapat gangguan dari orang yang berniat jahat. Wanita apalagi yang sedang hamil adalah sosok yang lemah secara fisik sehingga tidak aman bagi keselamatannya. Selain itu, dalam kepercayaan masyarakat setempat, wanita hamil yang keluar rumah pada waktu-waktu seperti itu akan membahayakan diri dan janinnya.

\section{PENUTUP}

Sebagaimana umumnya pandangan orang Labuan Bajo, lingkungan tempat mereka menetap sejak dari nenek moyang memberikan banyak pengaruh terhadap kepercayaan yang mereka jalani sehari-hari. Kepercayaan dan keyakinan tersebut juga tidak lepas dari pengaruh orang tua dulu sebagai pihak yang berperan besar dalam mengasuh dan mendidik anak-anaknya. Oleh karena itu, kepercayaan yang ada dalam komunitas masyarakat tersebut terlahir dari kepercayaan yang sudah ada sebelumnya. Ada kepercayaan yang sifatnya tidak dapat dijelaskan secara logika, tetapi pada kenyataannya masyarakat setempat masih terus menjaga dan melestarikan kepercayaan tersebut dengan alasan yang berbeda-beda, misalnya, takhayul. Takhayul sebagai produk masa lampau merupakan tradisi lisan masyarakat yang ditumbuhkembangkan secara sadar dan dipercaya oleh masyarakat penuturnya. Salah satu alasan mereka memercayainya adalah takut kualat atau kena tulah.

Pada dasarnya, orang Labuan Bajo hingga sekarang masih mengakui keberadaan takhayul, namun tingkat kepercayaannya sudah berkurang dibandingkan dengan kepercayaan yang dimiliki oleh para pendahulunya. Para pendahulu (nenek moyang) orang Labuan Bajo memandang takhayul sebagai suatu bentuk kepercayaan yang akan menimbulkan bahaya atau bencana apabila dilanggar, sedangkan orang Labuan Bajo sekarang sebagian besar memandang takhayul sebagai sarana menyampaikan pendidikan akhlak, etika, dan budi pekerti dalam lingkungannya agar masyarakat hidup lebih beradab dan berbudaya. Untuk itu, beberapa takhayul masih dipelihara dalam komunitas masyarakat tersebut.

Takhayul yang terdapat di sekitar lingkaran hidup manusia, khususnya yang berhubungan dengan kelahiran, masa bayi, dan kanak-kanak dipandang memiliki kedudukan yang strategis dalam kehidupan masyarakat Labuan Bajo sebagai salah satu paham kepercayaan lama yang harus ditaati oleh setiap anggota masyarakat penuturnya 
sejak masih berada dalam usia dini hingga dewasa. Cara pengungkapan takhayul dilakukan secara lisan, ada yang disampaikan secara langsung dan spontan ketika melihat pelaku melanggar suatu ketentuan ada pula dengan cara tidak langsung, yakni dengan memberikan pengetahuan awal terhadap tanda-tanda atau gejala-gejala alam yang dianggap memiliki makna tertentu sebagai bentuk peringatan agar lebih waspada.

Bentuk takhayul masyarakat Labuan Bajo pada umumnya adalah berbentuk kalimat majemuk sebab-akibat yang diawali dengan kata pengandaian atau larangan, disusul dengan hal (perbuatan) yang dilarangkan kemudian ditambahkan dengan kata penghubung "karena", dan terakhir diakhiri dengan pernyataan tentang keburukan atau akibat yang akan ditimbulkan oleh perbuatan yang dilarangkan itu. Selain itu, ada pula yang berbentuk lain, yakni berbentuk paparan biasa dengan berdasarkan pada sebuah tanda, misalnya ari-ari bayi dimasukkan ke dalam tempurung kelapa sebab tempurung kelapa itu diibaratkan sebagai kepala manusia yang memiliki dua mata, satu hidung, dan satu mulut seperti yang terdapat dalam tempurung kelapa.

Fenomena budaya masyarakat Labuan Bajo yang tergambar melalui takhayul memperlihatkan suatu kompleksitas budaya masyarakat penuturnya. Adanya pengetahuan tentang takhayul menunjukkan bahwa kepercayaan masyarakat setempat pada zaman dulu sangat dipengaruhi oleh paham animisme. Selain itu, takhayul juga menggambarkan tentang upaya orang tua dulu untuk menanamkan budaya malu, sopan santun, saling menghargai, dan tolong-menolong kepada masyarakat. Upaya tersebut berguna untuk penanaman sebuah karakter agar masyarakat tidak kehilangan identitas budaya ketimurannya.

Terakhir, saran singkat yang dapat penulis sampaikan terkait dengan persoalan takhayul yang dipaparkan melalui tulisan ini adalah perlunya pemeliharaan dan pelestarian takhayul beserta aspek-aspek budaya yang terkandung di dalamnya dalam perikehidupan masyarakat Labuan Bajo pada saat ini. Penutur takhayul tersebut kini sedang berada pada ketegangan antara percaya dengan tidak percaya dan antara mitos dengan realitas terhadap keberadaan takhayul. Apabila masyarakat penuturnya dapat memandang takhayul sebagai sebuah sarana untuk menyampaikan kebaikan dan realitas, maka keberadaan takhayul akan terus dipelihara dan dijaga. Namun, apabila takhayul hanya dipandang sebagai mitos belaka, sesuatu yang tidak berterima secara logika, sebagai bentuk keterbelakangan pola pikir, maka takhayul akan mudah tersisihkan dan dilupakan oleh masyarakat penuturnya. Untuk itu, takhayul harus bisa dijelaskan dan dihubungkan dengan realitas yang terdapat dalam masyarakat agar keberadaannya sebagai sebuah tradisi lisan dapat terus terjaga.

\section{DAFTAR SUMBER}

Ahimsa-Putra, Heddy Shry. 2006. Strukturalisme Levi-Strauss: Mitos dan Karya Sastra. Yogyakarta: Kepel Press.

Balawa, La Ode. 2010.

"Pomali: Kajian Aspek Didaktis dalam Budaya Masyarakat Berbahasa Ciacia di Kabupaten Buton". Kandai Vol 6 No 2. Kendari: Kantor Bahasa Provinsi Sulawesi Tenggara.

Brundvand, Jan Harold. 1968.

The Study of American Folklore An Introduction. New York: W.W. Norton \& Co. Inc.

Danandjaja, James. 1986.

Folklor Indonesia: Ilmu Gosip, Dongeng, dan lain-lain. Jakarta: Pustaka Grafitipers.

Dundes, Alan. 1961. 
Interpretating folklore.

Bloomington \& London: Indiana

University Press.

Endraswara, Suwardi. 2008.

Metodologi Penelitian Sastra.

Yogyakarta: FBS Universitas

Negeri Yogyakarta.

Hand, William D (ed.). 1952.

"Supertitions". The Frank $C$.

Brown Collection of North

Carolina Folklore (Newman Ivy

White and Paul F. Baum General

eds.) Vol VI \& VII. Durham. N. C.:

Duke University Press.
Kridalaksana, Harimurti. 1993.

Kamus Linguistik. Jakarta: PT Gramedia Pustaka Utama.

Ratna, Nyoman Kutha. 2006.

Teori, Metode, dan Teknik

Penelitian Sastra. Yogyakarta: Pustaka Pelajar.

Sugono, Dendy. 2008.

Kamus Besar Bahasa Indonesia (Cetakan Pertama Edisi IV).

Jakarta: PT Gramedia. 